REFLEKSI HUKUM

Jurnal Imu Hukum
p-ISSN 2541-4984 | e-ISSN 2541-5417

Volume 2 Nomor 1, Oktober 2017, Halaman 33 - 50

DOI: https://doi.org/10.24246/jrh.2017.v2.i1.p33-50

Open access at: http://ejournal.uksw.edu/refleksihukum Penerbit: Fakultas Hukum Universitas Kristen Satya Wacana

\title{
PITUTUR LUHUR UNTUK PEMBERANTASAN KORUPSI DI INDONESIA DALAM PERSPEKTIF KEBIJAKAN HUKUM PIDANA
}

\author{
Moch. Choirul Rizal \\ Penal Policy of Initiatives (POINTS) \\ Korepondensi: mcriza190@gmail.com \\ M. Lutfi Rizal Farid \\ Penal Policy of Initiatives (POINTS) dan \\ Fakultas Ilmu Sosial dan Hukum Universitas Negeri Surabaya \\ Korespondensi: lutrizal@gmail.com
}

\begin{abstract}
Abstrak
Studi ini memiliki fokus terhadap pitutur luhur untuk pemberantasan korupsi di Indonesia. Penulisan gagasan ini menggunakan pendekatan kebijakan hukum pidana. Ditemukan fakta bahwa pemberantasan korupsi selama ini belum menemukan keberhasilan yang signifikan. Salah satu indikatornya adalah Indeks Persepsi Korupsi bangsa Indonesia yang belum membaik. Ternyata, penindakan yang eksesif yang dilakukan oleh KPK tidak banyak mengurangi tingkat korupsi. Mengenai hal ini, rencana aksi yang sekiranya layak "diperjuangkan" secara optimal adalah pemberantasan korupsi secara preventif, tanpa kemudian mengurangi sedikitpun upaya-upaya represif. Ambil contoh, misalnya, merevitaliasi pitutur luhur yang merupakan salah satu kearifan lokal budaya Jawa. Dalam perspektif kebijakan hukum pidana, usaha menjadikan pitutur luhur untuk pemberantasan korupsi di Indonesia dapat dimaknai sebagai pengejawantahan upaya strategis untuk memperbaiki kondisi-kondisi sosial yang menjadi penyebab lahirnya praktik korupsi. Oleh karena itu, usaha konkritisasi pitutur luhur untuk pemberantasan korupsi di Indonesia dapat dilakukan dengan berbagai cara strategis, misalnya melalui dunia pendidikan, seni dan budaya, serta kegiatan-kegiatan yang melibatkan partisipasi masyarakat secara luas.
\end{abstract}

\section{Kata Kunci: Pitutur Luhur; Pemberantasan Korupsi; Kebijakan Hukum Pidana}

\begin{abstract}
The study has a focus on "pitutur luhur" for eradicating corruption in Indonesia. The writing of this idea uses a penal policy approach. It is found that the eradication of corruption has not found significant success. One indicator is the Indonesian Corruption Perceptions Index that has not improved. Apparently, the excessive action taken by the KPK does not reduce
\end{abstract}


the level of corruption much. In this regard, an action plan which is presumed to be worth "fighting" optimally is the eradication of corruption in a preventive manner, without then reducing any repressive efforts. Take, for example, revitalizing the "pitutur luhur" which is one of the local wisdom of Javanese culture. In the perspective of penal policy, efforts to make "pitutur luhur" for eradication of corruption in Indonesia can be interpreted as a manifestation of strategic efforts to improve social conditions that led to the birth of corrupt practices. Therefore, the concrete "pitutur luhur" effort to eradicate corruption in Indonesia can be done in various strategic ways, for example through the world of education, arts and culture, and activities that involve broad community participation.

Keyword: Pitutur Luhur; Eradication of Corruption; Penal Policy

\section{PENDAHULUAN}

Istilah dan sejarah lahirnya korupsi di dunia ini dapat dijumpai dalam berbagai literatur. ${ }^{1}$ Di sisi yang lain, kapan korupsi itu akan mati, masih menjadi diskursus yang tak kunjung berhenti. Nampaknya, korupsi sebagai salah satu bentuk kejahatan yang menemani kehidupan manusia di sepanjang masa. Mengenai hal ini, Saparinah Sadli pernah mengemukakan: ${ }^{2}$

Kejahatan merupakan salah satu bentuk dari perilaku menyimpang yang selalu ada dan melekat pada tiap bentuk masyarakat. Dengan kata lain, tidak ada masyarakat yang sepi dari kejahatan. Perilaku menyimpang itu merupakan suatu ancaman yang nyata terhadap norma-norma sosial yang mendasari kehidupan atau keteraturan sosial, dapat menimbulkan ketegangan individual maupun sosial, dan merupakan ancaman nyata atau potensial bagi berlangsungnya ketertiban sosial.
Bahkan, Ahmad Syafii Maarif pernah menyatakan: ${ }^{3}$

Korupsi adalah sumber segala bencana dan kejahatan, the root of all evils. Koruptor bahkan relatif lebih berbahaya dibandingkan teroris. Uang triliunan rupiah yang dijarah seorang koruptor, misalnya, adalah biaya hidup-mati puluhan juta penduduk miskin Indonesia. Dalam konteks itulah, koruptor adalah the real terrorist. Adalah mimpi di siang bolong untuk memberantas kemiskinan, meningkatkan pelayanan kesehatan, mempertinggi mutu pendidikan, dan lain-lain, bila korupsi masih dibiarkan menari-nari di depan mata.

Tumbuh suburnya praktik korupsi di negeri ini disebabkan oleh berbagai hal. Bibit S. Rianto menyebutnya sebagai Potensi Masalah Penyebab Korupsi (PMPK), yang terdiri atas: ${ }^{4}$

1. Sistem yang kurang baik atau tidak dilaksanakan secara benar, seperti sistem politik yang sarat dengan money politics, adanya mafia yang

$1 \quad$ Eggi Sudjana menyebut, korupsi sebagaimana yang dirumuskan dalam berbagai pengertian dan batasan sesungguhnya merupakan derivasi (turunan) atau hasil mutant dari berbagai kejahatan seperti pencurian, perampokan, serta penyalahgunaan kekuasaan dan kepercayaan masyarakat (abuse of power). Dari perspektif ini sesungguhnya usia korupsi telah sangat tua. Menurut beberapa catatan sejarah, praktik suap-menyuap atau pemberian uang sogokan telah dikenal pada zaman Romawi Kuno dalam bentuk penyuapan terhadap hakim yang mengadili perkara. Eggi Sudjana, Republik Tanpa KPK, Koruptor Harus Mati (JP Books 2008) 1.

$2 \quad$ Saparinah Sadli, Persepsi Sosial mengenai Perilaku Menyimpang (Bulan Bintang 1976) 56.

3 Denny Indrayana, Negeri Para Mafioso: Hukum di Sarang Koruptor (Penerbit Buku Kompas 2008) ix.

4 Bibit S. Rianto dan Nurlis Meuko, Koruptor, Go to Hell! (Mengupas Anatomi Korupsi di Indonesia) (Hikmah 2010) 27-28. 
menentukan sistem ekonomi, dan adanya mafia peradilan.

2. Integritas moral pejabat dan masyarakat yang rendah atau suka menempuh jalan pintas dengan menghalalkan segala macam cara.

3. Remunerasi yang tidak rasional, dalam arti belum cukup untuk hidup secara layak.

4. Kontrol atau pengawasan yang lemah, baik internal maupun eksternal serta self controlyang menimbulkan peluang untuk melakukan korupsi.

5. Budaya taat kepada hukum yang lemah, sehingga tidak tahu lagi mana yang salah dan mana yang benar. Bahkan, ada pameo: hukum yang dibuat adalah untuk dilanggar.

Di Indonesia, istilah korupsi semula hanyalah bersifat umum dan baru mendapat istilah hukum untuk pertama kalinya dalam peraturan penguasa militer Nomor PRT/PM/06/1957 tentang Pemberantasan Korupsi. Dalam konsideran peraturan tersebut dikatakan antara lain bahwa: ${ }^{5}$

"Berhubung dengan tidak adanya kelancaran dalam usaha memberantas dalam perbuatan-perbuatan yang merugikan keuangan negara dan perekonomian negara yang oleh khalayak dinamakan korupsi, perlu segera menetapkan suatu tata kerja untuk dapat menerobos kemacetan usaha memberantas korupsi."

Upaya pemberantasan korupsi di Indonesia melalui pembentukan peraturan perundang-undangan setingkat undang-undang menjadi suatu pilihan yang mutlak. Sampai dengan saat ini, ada beberapa undang-undang yang relevan, antara lain sebagai berikut: 6

1. Peraturan Pemerintah Pengganti Undang-Undang Nomor 24 Tahun 1960 tentang Pengusutan, Penuntutan, dan Pemeriksaan Tindak Pidana Korupsi;

2. Undang-Undang Nomor 3 Tahun 1971 tentang Pemberantasan Tindak Pidana Korupsi;

3. Undang-Undang Nomor 28 Tahun 1999 tentang Penyelenggaraan Negara yang Bersih dan Bebas Korupsi, Kolusi, dan Nepotisme;

4. Undang-Undang Nomor 31 Tahun 1999 tentang Pemberantasan Tindak Pidana Korupsi;

Sudarto, Hukum dan Hukum Pidana (Alumni 2000) 115.

Berdasarkan Firman Raja Belanda (Koninklijke Besluit) tertanggal 15 Oktober 1915 (Stbl. Nomor 752 Tahun 1915) diberlakukanlah WvSNI atau dikenal dengan KUHP di masa kemerdekaan. Di dalam Pasal 423 KUHP itulah mulai dikenal suatu tindak pidana yang disebut sebagai kejahatan jabatan, yang kemudian dalam perkembangannya disebut sebagai tindak pidana korupsi. Seiring perkembangan zaman perjuangan waktu itu, dibentuklah Peraturan Penguasa Militer Prt/PM/06/1957, Prt/PM/03/1957, dan Prt/PM/11/1957, kemudian diganti dengan Peraturan Perang Pusat Nomor Prt/Perpu/013/1958, yang selanjutnya diganti dengan Peraturan Pemerintah Pengganti Undang-Undang Nomor 24 Tahun 1960 tentang Pengusutan, Penuntutan, dan Pemeriksaan Tindak Pidana Korupsi. Lihat, Alfian Wahyu Pratama, 'Kebijakan Hukum Pidana dalam Menanggulangi Tindak Pidana Korupsi yang Dilakukan Korporasi (Studi Pembaruan Pidana dalam Menanggulangi Tindak Pidana Korupsi yang Dilakukan Korporasi)' (2013) <http://jurnal.untan.ac.id/index.php/nestor/article/view/977>diakses 1 Januari 2018. Lihat juga, Ernest Runtukahu, 'Korupsi dalam Konsep Hukum Formal dan Konsep Hukum Material' (2012) 1 Jurnal Lex Crimen 1, 73-82. 
5. Undang-Undang Nomor 20 Tahun 2001 tentang Perubahan atas Undang-Undang Nomor 31 Tahun 1999 tentang Pemberantasan Tindak Pidana Korupsi;

6. Undang-Undang Nomor 30 Tahun 2002 tentang Komisi Pemberantasan Tindak Pidana Korupsi; dan

7. Undang-Undang Nomor 7 Tahun 2006 tentang Pengesahan United Nation Convention Against Corruption, 2003 (Konvensi Perserikatan BangsaBangsa Anti Korupsi, 2003).

Mendasarkan pada berbagai aturan hukum yang ada, pemberantasan korupsi di Indonesia dilakukan dengan pola deteksi-aksi melalui kegiatankegiatan sebagai berikut: ${ }^{7}$

1. Kegiatan deteksi, yakni dimaksudkan sebagai kegiatan mengumpulkan keterangan yang diolah menjadi informasi tentang kerawanan korupsi. Kemudian diprediksi sasaran kerawanan korupsi yang mungkin dihadapi dalam kurun waktu tertentu serta mendukung informasi lanjutan dalam proses penindakan tindak pidana korupsi.

2. Kegiatan preemtif, yakni penanganan pada hulu permasalahan korupsi atau akar masalah korupsi berupa potensi masalah penyebab korupsi (kesisteman, integritas moral, remunerasi yang layak, kontrol yang efektif, dan budaya taat hukum yang andal) serta bekerja sama untuk mewujudkan kepentingan bangsa berdasarkan hukum.
3. Kegiatan preventif, yakni kegiatan pencegahan terjadinya korupsi dengan tujuan membuat segenap entitas dalam masyarakat aman dari korupsi (tidak memberi peluang terjadinya korupsi) serta menjaga agar kerawanan korupsi tidak dimanfaatkan para koruptor.

4. Kegiatan represif, yakni dengan melakukan penyelidikan, penyidikan, dan penuntutan terhadap pelaku, melakukan upaya hukum lanjutan, serta melaksanakan putusan hakim yang telah memiliki kekuatan hukum yang tetap.

5. Kegiatan rehabilitasi, yakni pemulihan akibat terjadinya korupsi, baik berupa mengembalikan kerugian masyarakat dan negara yang diderita akibat korupsi baik dengan menarik uang pengganti, penelusuran aset yang dikorupsi, serta memulihkan kondisi fisik maupun psikologis akibat korupsi.

Melihat berbagai kegiatan dalam upaya pemberantasan korupsi sebagaimana tersebut di atas, seharusnya Indonesia dapat bebas korupsi. Namun sebaliknya, praktik korupsi di negeri ini kian hari kian tampak sebagai realitas yang biasa terjadi. Apakah hal ini semakin dapat meneguhkan pendapat bahwa korupsi sebagai budaya masyarakat Indonesia? Pertanyaan semacam ini masih menjadi suatu perdebatan yang tiada kunjung habisnya. Pertanyaan lebih lanjut adalah upaya apa

Bibit S. Rianto dan Nurlis Meuko, Op.Cit., 29-31. 
yang dapat dilakukan untuk pemberantasan korupsi di Indonesia?

Sejak tahun 2002, Komisi Pemberantasan Tindak Pidana Korupsi (atau disebut "KPK") secara formal merupakan lembaga antikorupsi yang dimiliki oleh Indonesia. Pembentukan KPK didasari oleh Undang-Undang Nomor 30 Tahun 2002 tentang Komisi Pemberantasan Tindak Pidana Korupsi. Sesuai dengan undang-undang tersebut, KPK memiliki tugas sebagai berikut: ${ }^{8}$

1. Koordinasi dengan instansi yang berwenang melakukan pemberantasan tindak pidana korupsi;

2. Supervisi terhadap instansi yang berwenang melakukan pemberantasan tindak pidana korupsi;

3. Penyelidikan, penyidikan, dan penuntutan terhadap tindak pidana korupsi;

4. Melakukan tindakan-tindakan pencegahan tindak pidana korupsi; dan

5. Melakukan pemantauan (monitoring) penyelenggaraan pemerintahan negara.

Tuntutan pendirian lembaga antirasuah tersebut muncul akibat keputusasaan publik akan lemahnya kinerja 3 (tiga) penegak hukum di Indonesia, yaitu polisi, jaksa, dan hakim dalam memberantas korupsi yang semakin merajalela. Institusi tersebut seolah tidak berfungsi untuk menindak para koruptor sebagaimana mestinya, bahkan seolah-olah dijadikan "tambang emas" oleh oknum pada 3 (tiga) institusi yang dimaksud. Pada perkembangannya kemudian, penanganan tindak pidana korupsi yang dahulu seperti tidak tersentuh, apalagi dituntaskan oleh para penegak hukum yang ada sebelum KPK lahir, akhirnya ditangani lebih serius. ${ }^{9}$

Walaupun Indonesia telah memiliki lembaga "super body" untuk memberantas korupsi, menurut Global Corruption Barometer, sebagaimana dikutip oleh Dave Akbarshah Fikarno Laksono dalam opininya, dilihat dari segi kinerja, strategi KPK dalam pemberantasan korupsi selama ini masih lemah, yakni dapat dilihat dari belum membaiknya Indeks Persepsi Korupsi bangsa Indonesia. Ternyata, penindakan yang eksesif yang dilakukan oleh KPK tidak banyak mengurangi tingkat korupsi. Lebih lanjut, masih menurut Dave, baru di tahun 2016 KPK mengajukan usulan anggaran pencegahan yang lebih besar dari anggaran penindakan kepada DPR untuk pagu anggaran tahun 2016. Dalam RKA 2016 KPK mengajukan usulan anggaran pencegahan sebesar Rp114.395.095.000, sedangkan untuk penindakan Rp63.737.986.000 (Laporan Singkat RDP Komisi III DPR RI, 2016). ${ }^{10}$

$8 \quad$ Achmad Badjuri, 'Peranan Komisi Pemberantasan Korupsi (KPK) sebagai Lembaga Antikorupsi di Indonesia' (2011) 18 Jurnal Bisnis dan Ekonomi 1, 89.

9 Endarto, 'Kendala KPK dalam Pemberantasan Korupsi di Indonesia' (2014) 1 Jurnal Lingkar Widyaiswara 1, 6-15. 
Kritik dari anggota Komisi I DPR RI sebagaimana tersebut di atas patut untuk dijadikan cermin atas strategi pemberantasan korupsi yang sudah dilaksanakan selama ini. Setidaknya adalah untuk melakukan "balancing" antara upaya preventif dengan represif. Upaya preventif yang dimaksud, salah satunya, adalah merevitalisasi peran kearifan lokal sebagai bagian dari strategi pemberantasan korupsi di Indonesia. Ambil contoh, misalnya, merevitaliasi pitutur luhur yang merupakan salah satu kearifan lokal budaya Jawa. Oleh karena itu, studi gagasan ini akan fokus terhadap pitutur luhur untuk pemberantasan korupsi di Indonesia dalam perspektif kebijakan hukum pidana.

Perpaduan berbagai aksi dalam pemberantasan korupsi sesungguhnya adalah sebuah jawaban. Sekalipun upaya preventif sudah dilakukan, bahkan represif pun kian menghebohkan, sinergisitas antar kedua upaya tersebut tidak boleh kendur. Mengutip sebagian lirik lagu yang dinyanyikan Iwan Fals, kedua upaya tersebut dapat diibaratkan sebagai persembahan dari kelompok paduan suara yang tengah tampil: "nada beda, harmoni tetap dijaga." Tentu, perpaduan demikian memerlukan komitmen, kerja keras, dan dukungan masyarakat luas.

\section{PEMBAHASAN}

\section{Pelemahan Pemberantasan Korupsi di Indonesia}

KPK dibentuk untuk melaksanakan tugas dan kewenangannya dalam pemberantasan korupsi di Indonesia yang bersifat independen dan bebas dari pengaruh kekuasaan manapun. Dalam hal ini, KPK bebas dari kekuatan yang dapat mempengaruhi tugas dan wewenang KPK atau anggota komisi secara individual dari pihak eksekutif, yudikatif, legislatif, pihakpihak lain yang terkait dengan perkara tindak pidana korupsi, atau keadaan dan situasi ataupun dengan alasan apapun.

Dalam menangani perkara, KPK diberi kewenangan memperpendek jalur birokrasi dan proses dalam penuntutan. Jadi, KPK mengambil sekaligus 2 (dua) peranan, yaitu tugas kepolisian dan kejaksaan yang selama ini kurang berdaya dalam memerangi korupsi. Melihat kewenangan KPK, maka tidak heran kalau kalangan hukum menyebutnya sebagai lembaga super (super body). Peran dan fungsi KPK tidak lain adalah untuk meningkatkan daya dan hasil guna terhadap upaya pemberantasan tindak pidana korupsi. ${ }^{11}$

Namun demikian, perjalanan KPK dalam kerja-kerja pemberantasan korupsi di Indonesia tidak dapat dika-

10 Dave Akbarshah Fikarno Laksono, 'Efektivitas Politik Pemberantasan Korupsi' (2017) <http:// koran-sindo.com/page/news/2017-07-24/1/1/Efektivitas_Politik_Pemberantasan_Korupsi> diakses 23 Agustus 2017.

11 Totok Sugiarto, 'Peranan Komisi Pemberantasan Korupsi (KPK) dalam Pemberantasan Tindak Pidana Korupsi di Indonesia' (2013) 18 Jurnal Cakrawala Hukum 1, 188-196. 
takan bebas dari pengaruh kekuasaan manapun. Artinya, ada saja upayaupaya dari pihak-pihak yang "tidak suka" dengan KPK untuk melemahkan bahkan berinisiatif untuk membubarkan komisi antirasuah tersebut.

Sebagaimana terurai secara singkat pada Tabel 1, lengkap sudah pelemahan-pelemahan terhadap KPK. Masih merujuk pada data di atas, pelemahan terhadap KPK didominasi dalam bentuk hambatan penyidikan. Hal ini mafhum, karena memang kerja-kerja penindakan oleh KPK benar-benar memalukan dan mengganggu "sumber pendapatan" bagi para pihak yang pro terhadap kejahatan maha haram tersebut.

Tabel 1 Pelemahan terhadap KPK dari Masa ke Masa

\begin{tabular}{|c|c|c|c|c|}
\hline No. & Kepemimpinan & Waktu & $\begin{array}{c}\text { Bentuk } \\
\text { Pelemahan }\end{array}$ & Uraian \\
\hline 1 . & $\begin{array}{l}\text { Antasari Azhar } \\
(2007-2009)\end{array}$ & $8 / 2 / 2008$ & $\begin{array}{l}\text { Hambatan } \\
\text { Penyidikan }\end{array}$ & $\begin{array}{l}\text { KPK mendapat ancaman } \\
\text { bom saat tengah } \\
\text { memeriksa Dewan } \\
\text { Gubernur Bank Indonesia } \\
\text { periode 1999-2004, Aulia } \\
\text { Pohan. }\end{array}$ \\
\hline 2. & & $2 / 7 / 2009$ & $\begin{array}{l}\text { Pernyataan } \\
\text { Politik }\end{array}$ & $\begin{array}{l}\text { Kabareskrim Mabes Polri, } \\
\text { Susno Duadji, } \\
\text { mencetuskan istilah } \\
\text { "Cicak dengan Buaya" } \\
\text { dalam sebuah wawancara } \\
\text { di media. Ilustrasi yang } \\
\text { diberikan Susno tersebut } \\
\text { lalu menyulut reaksi keras } \\
\text { publik terhadap Polri. }\end{array}$ \\
\hline 3. & & $15 / 9 / 2009$ & Kriminalisasi & $\begin{array}{l}\text { Bibit Sanad Rianto dan } \\
\text { Chandra Hamzah } \\
\text { ditetapkan sebagai } \\
\text { tersangka atas dugaan } \\
\text { kasus penerimaan suap } \\
\text { dan penyalahgunaan } \\
\text { wewenang dalam } \\
\text { pemberian surat cekal bagi } \\
\text { Direktur PT Masaro, } \\
\text { Anggoro Widjojo, dalam } \\
\text { kasus Sistem Komunikasi } \\
\text { Radio Terpadu Dephut } \\
\text { serta buronan "cassie" } \\
\text { Bank Bali, Joko Tjandra. }\end{array}$ \\
\hline 4. & & $29 / 10 / 2009$ & $\begin{array}{l}\text { Berkurangnya } \\
\text { Komisioner KPK }\end{array}$ & $\begin{array}{l}\text { Polri menahan Wakil } \\
\text { Ketua KPK (nonaktif) Bibit } \\
\text { Samad Rianto dan } \\
\text { Chandra M. Hamzah atas } \\
\text { tuduhan penyalahgunaan } \\
\text { wewenang dan pemerasan } \\
\text { terkait kasus Anggoro } \\
\text { Widjojo. }\end{array}$ \\
\hline
\end{tabular}




\section{Lanjutan Tabel 1}

\begin{tabular}{|c|c|c|c|c|}
\hline No. & Kepemimpinan & Waktu & $\begin{array}{c}\text { Bentuk } \\
\text { Pelemahan }\end{array}$ & Uraian \\
\hline 12. & & $2 / 8 / 2012$ & $\begin{array}{l}\text { Hambatan } \\
\text { Penyidikan }\end{array}$ & $\begin{array}{l}\text { Polri mengirimkan Surat } \\
\text { Pemberitahuan } \\
\text { Dimulainya Penyidikan } \\
\text { (SPDP) kasus korupsi } \\
\text { pengadaan simulator di } \\
\text { Korlantas ke kejaksaan. } \\
\text { SPDP itu disertai nama- } \\
\text { nama tersangka yang } \\
\text { sebenarnya sudah } \\
\text { ditetapkan KPK sebagai } \\
\text { tersangka. Usaha ini } \\
\text { dilakukan untuk } \\
\text { mengambil alih wewenang } \\
\text { penyidikan kasus tersebut. }\end{array}$ \\
\hline 13. & & $5 / 10 / 2012$ & $\begin{array}{l}\text { Hambatan } \\
\text { Penyidikan }\end{array}$ & $\begin{array}{l}\text { Malam hari setelah KPK } \\
\text { pertama kali memeriksa } \\
\text { Djoko Susilo sebagai } \\
\text { tersangka kasus korupsi } \\
\text { pengadaan simulator SIM } \\
\text { Korlantas, sejumlah polisi } \\
\text { dari Polda Bengkulu dan } \\
\text { Polda Metro Jaya } \\
\text { mendatangi KPK untuk } \\
\text { menjemput paksa penyidik } \\
\text { KPK, Novel Baswedan, } \\
\text { yang menjadi tersangka } \\
\text { kasus penganiayaan berat } \\
\text { saat bertugas di Polres } \\
\text { Bengkulu tahun 2004. }\end{array}$ \\
\hline 14. & & $5 / 10 / 2012$ & Politik Hukum & $\begin{array}{l}\text { Sejumlah perwira polisi } \\
\text { menjemput paksa penyidik } \\
\text { Polri yang masih bertugas } \\
\text { di KPK terkait kasus Novel } \\
\text { Baswedan. }\end{array}$ \\
\hline 15 . & & 2012 & $\begin{array}{l}\text { Hambatan } \\
\text { Penyidikan }\end{array}$ & $\begin{array}{l}\text { Hingga akhir } 2012 \text {, terjadi } \\
\text { penarikan } 31 \text { penyidik } \\
\text { KPK oleh Polri. Sebelum } \\
\text { ditarik, jumlah penyidik } \\
\text { KPK tak lebih dari } 100 \\
\text { orang. }\end{array}$ \\
\hline 16. & & $6 / 6 / 2013$ & $\begin{array}{l}\text { Hambatan } \\
\text { Penyidikan }\end{array}$ & $\begin{array}{l}\text { Upaya KPK menyita mobil } \\
\text { Luthfi Hasan Ishaaq di } \\
\text { DPP PKS dihalangi para } \\
\text { kader partai ini. PKS pun } \\
\text { melaporkan KPK kepada } \\
\text { Mabes Polri karena tidak } \\
\text { mengikuti prosedur dalam } \\
\text { penyitaan mobil tersebut. }\end{array}$ \\
\hline 17. & & $3 / 10 / 2011$ & $\begin{array}{l}\text { Pernyataan } \\
\text { Politik }\end{array}$ & $\begin{array}{l}\text { Dalam rapat konsultasi } \\
\text { DPR dengan lembaga } \\
\text { penegak hukum, Wakil } \\
\text { Ketua Komisi III DPR, } \\
\text { Fahri Hamzah, mengusung } \\
\text { wacana pembubaran KPK, } \\
\text { karena menurut dia dalam } \\
\text { sebuah negara yang } \\
\text { menganut sistem } \\
\text { demokrasi tidak boleh ada } \\
\text { lembaga yang sangat kuat } \\
\text { dan "superbody" seperti } \\
\text { KPK. }\end{array}$ \\
\hline
\end{tabular}


Lanjutan Tabel 1

\begin{tabular}{|c|c|c|c|c|}
\hline No. & Kepemimpinan & Waktu & $\begin{array}{c}\text { Bentuk } \\
\text { Pelemahan }\end{array}$ & Uraian \\
\hline 18. & & $23 / 1 / 2015$ & Kriminalisasi & $\begin{array}{l}\text { Wakil Ketua KPK Bambang } \\
\text { Widjojanto ditangkap dan } \\
\text { ditetapkan sebagai } \\
\text { tersangka dalam kasus } \\
\text { suap Pilkada Kabupaten } \\
\text { Kotawaringin Barat. }\end{array}$ \\
\hline 19. & $\begin{array}{l}\text { Agus Rahardjo } \\
(2015-2019)\end{array}$ & $1 / 2 / 2017$ & Politik Hukum & $\begin{array}{l}\text { Draf revisi UU KPK mulai } \\
\text { dibahas dalam rapat } \\
\text { harmonisasi Baleg DPR RI. }\end{array}$ \\
\hline 20. & & $11 / 4 / 2017$ & $\begin{array}{l}\text { Hambatan } \\
\text { Penyidikan }\end{array}$ & $\begin{array}{l}\text { Salah satu penyidik senior } \\
\text { KPK, Novel Baswedan, } \\
\text { mendapat serangan fisik di } \\
\text { dekat masjid di sekitar } \\
\text { rumahnya, Selasa } \\
(11 / 4 / 2017) \text {. Ada } \\
\text { informasi dari pihak } \\
\text { keluarga bahwa Novel } \\
\text { Baswedan disiram air } \\
\text { keras oleh seseorang yang } \\
\text { belum diketahui } \\
\text { identitasnya. }\end{array}$ \\
\hline 21. & & $28 / 4 / 2017$ & Politik Hukum & $\begin{array}{l}\text { Melalui rapat paripurna, } \\
\text { Jumat ( } 28 / 4 / 2017), \text { DPR } \\
\text { RI menyetujui usulan hak } \\
\text { angket yang ditujukan } \\
\text { Komisi III kepada KPK. }\end{array}$ \\
\hline
\end{tabular}

Sumber: Diolah dari pemberitaan-pemberitaan media massa Kompas. ${ }^{12}$

Mengingat kuatnya pelemahan terhadap KPK dan adanya tugas untuk melakukan pencegahan tindak pidana korupsi di sisi yang lain, keterpaduan antara upaya represif dan preventif adalah suatu keniscayaan. Lebih khusus terhadap upaya preventif dalam pemberantasan korupsi di Indonesia, misalnya melalui optimalisasi nilai-nilai luhur bangsa, KPK dapat memanfaatkannya sebagai jalan lain yang sesungguhnya sangat strategis untuk jangka waktu yang sangat panjang ke depan. Dalam hal ini, secara tidak langsung, konkritisasi nilai-nilai luhur bangsa mempunyai pengaruh preventif terhadap kejahatan korupsi di Indonesia.

\section{Pitutur Luhur dalam Kearifan Lokal Budaya Jawa}

Pitutur luhur berbentuk petuah yang dikemas secara filosofis tentang bagaimana mencapai keharmonisan kehidupan dan menjadi anggota masyarakat

\footnotetext{
12 Kompas, 'Upaya-Upaya Pelemahan KPK' (2015) Kompas 24 Januari 2015, 3. Lihat juga, Kompas, 'Ini 45 Anggota DPR Pengusul Revisi UU KPK' (2016) <http:/ / nasional.kompas.com/read/2016/ 02/05/10524641/Ini.45.Anggota.DPR.Pengusul.Revisi.UU.KPK> diakses 25 Juli 2017; Kompas, 'Penyidik KPK Novel Baswedan Disiram Air Keras', (2017) <http:/ / nasional. kompas.com/read/ 2017/04/11/07372071/penyidik.kpk. novel. baswedan. disiram. air.keras> diakses 25 Juli 2017; dan Kompas, 'Drama Rapat Paripurna DPR Loloskan Hak Angket KPK...', (2017) <http:/ / nasional.kompas.com/read/2017/04/29/10095821/drama. rapat. paripurna. dpr.loloskan.hak.angket.kpk.?page=1> diakses 25 Juli 2017.
} 
yang baik. ${ }^{13}$ Dalam Bausastra Jawa, kata "pitutur" berasal dari bahasa Jawa Kuna yang berarti "pelajaran, nasihat, atau peringatan", ${ }^{14}$ sedangkan kata "luhur" berasal dari bahasa Kawi yang berarti "tinggi, mulia, atau baik. ${ }^{15}$ Dengan demikian, dapat diambil kesim-pulan bahwa pengertian dari "pitutur luhur" adalah pelajaran yang berupa nasihatnasihat yang mempunyai nilai-nilai tinggi, mulia, dan baik.

Berdasarkan pada beberapa referensi sebagaimana dikutip oleh Sunardi, berikut disajikan beberapa pitutur luhur dan makna pokok yang terkandung di dalamnya: ${ }^{16}$

Tabel 2 Pitutur Luhur Jawa dan Makna Pokoknya

\begin{tabular}{|c|c|c|}
\hline No. & Pitutur Luhur & Makna Pokok \\
\hline 1. & $\begin{array}{l}\text { Sugih tanpa bandha } \\
\text { (kaya tanpa harta). }\end{array}$ & $\begin{array}{l}\text { Kata "sugih" pada pitutur luhur ini mengarah } \\
\text { pada konsep kekayaan secara batiniah. } \\
\text { Ketika seseorang banyak dibutuhkan oleh } \\
\text { orang lain, secara batiniah sebenarnya ia } \\
\text { sudah menjadi orang kaya. Tatkala } \\
\text { kehadiran kita sangat berarti bagi orang } \\
\text { lain, pada saat itu kita seharusnya merasa } \\
\text { bersyukur atas anugerah Tuhan Yang Maha } \\
\text { Kuasa yang telah memberikan kelebihan, } \\
\text { sehingga kita mendapat kesempatan untuk } \\
\text { menanam kebaikan (nandur kebecikan). }\end{array}$ \\
\hline 2. & $\begin{array}{l}\text { Digdaya tanpa aji (tak } \\
\text { terkalahkan tanpa } \\
\text { kesaktian). }\end{array}$ & $\begin{array}{l}\text { Kata "digdaya" artinya tidak terkalahkan } \\
\text { dengan segala jenis senjata. "Aji" (kesaktian) } \\
\text { bisa berupa mantra (misalnya lembusekilan, } \\
\text { balaseribu, dan sasrabirawa) atau benda } \\
\text { (misalnya keris, akik, pedang, gada besi } \\
\text { kuning, dan panah). "Digdaya" (sakti) secara } \\
\text { batinlah yang terjadi ketika kita tidak punya } \\
\text { musuh, tidak pernah menyakiti hati orang } \\
\text { lain, tepaselira, tenggang rasa. Tentunya itu } \\
\text { akan membuat kita menjadi orang merdeka } \\
\text { yang tentrem (tentram), ayem (tidak terusik), } \\
\text { dan lerem (mengedepankan pikiran). }\end{array}$ \\
\hline 3. & $\begin{array}{l}\text { Nglurug tanpa bala } \\
\text { (menyerbu tanpa } \\
\text { pasukan). }\end{array}$ & $\begin{array}{l}\text { Hidup laksana pertempuran abadi, bukan } \\
\text { secara fisik, namun secara batiniah. Musuh } \\
\text { kita bukanlah lingkungan kita (orang lain), } \\
\text { tetapi adalah nafsu kita sendiri. Lebih baik } \\
\text { kita hidup apa adanya sesuai dengan } \\
\text { kemampuan kita. Sifat mengeluh saat kita } \\
\text { berada dalam kekurangan dan rasa } \\
\text { sombong rohani untuk menunjukkan kita } \\
\text { paling suci harus kita jauhi agar kita bisa } \\
\text { menjadi pemenang. Ketulusan dan } \\
\text { keikhlasan hati merupakan kunci } \\
\text { kebahagiaan hidup. }\end{array}$ \\
\hline
\end{tabular}

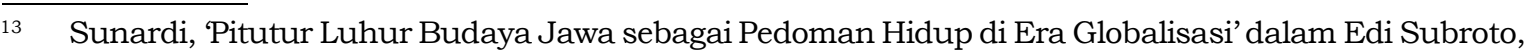
dkk, Prosiding Seminar Nasional: Reaktualisasi Nilai-Nilai Luhur Budaya Jawa melalui Bahasa Jawa (Program Studi Pendidikan Bahasan dan Sastra Daerah Universitas Veteran Bantara Sukoharjo 2012) 58.

14 S. Prawiroatmodjo, Bausastra Jawa-Indonesia (Express dan Marfiah 1957) 507.

$15 \quad$ Ibid, 268.

16 Sunardi, Op.Cit., 60-62. 


\section{Lanjutan Tabel 2}

\begin{tabular}{|c|c|c|}
\hline No. & Pitutur Luhur & Makna Pokok \\
\hline 4. & $\begin{array}{l}\text { Menang tanpa ngasorake } \\
\text { (menang tanpa } \\
\text { merendahkan). }\end{array}$ & $\begin{array}{l}\text { Keberhasilan mencapai cita-cita janganlah } \\
\text { menimbulkan masalah bagi orang lain. } \\
\text { Sebaliknya, keberhasilan yang kita capai } \\
\text { sebisa mungkin harus memberi manfaat } \\
\text { bagi orang lain, sehingga dalam } \\
\text { keberhasilan kita tidak terkandung } \\
\text { kesedihan orang lain. }\end{array}$ \\
\hline 5. & $\begin{array}{l}\text { Trimah mawi pasrah } \\
\text { (menerima dengan } \\
\text { pasrah). }\end{array}$ & $\begin{array}{l}\text { Baik dan buruk yang terjadi pada kita selalu } \\
\text { mengandung hikmah. Dari yang baik yang } \\
\text { terjadi pada kita bermakna bahwa kita } \\
\text { seyogyanya harus melakukan yang lebih } \\
\text { baik lagi dan buruk yang terjadi pada kita } \\
\text { juga dapat kita maknai bahwa kita harus } \\
\text { berinstropeksi diri dan mencari yang benar. } \\
\text { Segala sesuatu yang terjadi ada maksud dan } \\
\text { tujuan dari Tuhan Yang Maha Kuasa. }\end{array}$ \\
\hline 6. & $\begin{array}{l}\text { Suwung pamrih tebih } \\
\text { ajrih (jika tanpa pamrih } \\
\text { tidak perlu takut). }\end{array}$ & $\begin{array}{l}\text { Apalah artinya tangisan hanya gara-gara } \\
\text { ingin dipuji, dibalas, atau diberi, jika } \\
\text { kemuliaan jauh dari kita. Yang terpenting } \\
\text { adalah kedamaian, ketentraman, aman, } \\
\text { kebahagiaan, dan kemuliaan. Pamrih itu } \\
\text { hanya membuat seseorang menjadi penakut, } \\
\text { picik, menderita, menjenuhkan, bahkan } \\
\text { dapat membuat orang menjadi hina. }\end{array}$ \\
\hline 7. & $\begin{array}{l}\text { Sepi ing pamrih rame ing } \\
\text { gawe (sepi dalam } \\
\text { pamrih, ramai dalam } \\
\text { bekerja). }\end{array}$ & $\begin{array}{l}\text { Pitutur luhur ini menanamkan pada kita } \\
\text { bahwa bekerja keras itu tak perlu banyak } \\
\text { pamrih (mengharapkan sesuatu). Jadi, } \\
\text { kalau kita mau membantu orang lain, tidak } \\
\text { perlu memikirkan pamrih (mengharapkan } \\
\text { sesuatu dari orang yang kita bantu). } \\
\text { Meninggalkan kesan baik pada orang yang } \\
\text { kita bantu bernilai jauh lebih luar biasa } \\
\text { daripada sesuatu yang kita harapkan. }\end{array}$ \\
\hline 8. & $\begin{array}{l}\text { Mulat sarira hangrasa } \\
\text { wani (berani mawas } \\
\text { diri). }\end{array}$ & $\begin{array}{l}\text { Pitutur luhur ini mempunyai arti bahwa } \\
\text { berani melihat diri kita sendiri dengan } \\
\text { segala kekurangannya dan selalu siap } \\
\text { mendapat kritik dari siapapun dan } \\
\text { kapanpun. Ajaran agama apapun selalu } \\
\text { mengajarkan bahwa sebagai umat yang } \\
\text { lemah hendaknya kita selalu berinstropeksi. }\end{array}$ \\
\hline
\end{tabular}

Dalam upaya pemberantasan korupsi di Indonesia, khususnya pada aspek pencegahan, perlu ada pemaknaan terhadap masing-masing pitutur luhur, sehingga ada korelasi yang jelas antara keduanya, sebagaimana diuraikan pada Tabel 3.
Pitutur Luhur untuk Pemberantasan Korupsi di Indonesia

Ancaman-ancaman nyata atau potensial dari suatu kejahatan itu telah diupayakan untuk diredam dengan berbagai usaha. Salah satu usaha pencegahan dan pengendalian kejahatan itu ialah dengan menggunakan 
Tabe1 3 Pemaknaan Pitutur Luhur Jawa untuk Pemberantasan Korupsi

\begin{tabular}{|c|c|c|}
\hline No. & Pitutur Luhur & Pemaknaan untuk Pemberantasan Korupsi \\
\hline & $\begin{array}{l}\text { Sugih tanpa bandha } \\
\text { (kaya tanpa harta). }\end{array}$ & $\begin{array}{l}\text { Setiap orang pada hakikatnya dianugerahi } \\
\text { oleh Tuhan berbagai kelebihan dan } \\
\text { kesempatan untuk menanam kebaikan } \\
\text { kepada orang lain tanpa melihat kuantitas } \\
\text { ekonominya. Dalam konteks ini, setiap } \\
\text { orang seharusnya mampu untuk berbuat } \\
\text { kebaikan kepada orang lain dengan tidak } \\
\text { melakukan perbuatan yang koruptif. }\end{array}$ \\
\hline
\end{tabular}

2. Digdaya tanpa aji (tak terkalahkan tanpa kesaktian).

3. Nglurug tanpa bala (menyerbu tanpa pasukan).
Setiap orang yang diberikan kesempatan untuk berkuasa seharusnya tidak pernah menyakiti hati orang lain, misalnya melakukan tindak pidana korupsi, sehingga akan ia akan menjadi orang merdeka yang tentrem (tentram) dan lerem (mengedepankan pikiran) untuk kemanfaatan banyak orang.

Setiap orang memiliki "musuh abadi", yakni nafsunya sendiri. Oleh karenanya, setiap orang yang diberikan amanah untuk memimpin harus dapat mengalahkan nafsunya sendiri, misalnya dengan hidup apa adanya sesuai dengan kemampuannya. Dengan demikian, tidak akan terbersit suatu pikiran untuk melakukan perbuatan koruptif.

4. Menang tanpa ngasorake (menang tanpa merendahkan).

5. Trimah mawi pasrah (menerima dengan pasrah).

6. Suwung pamrih tebih ajrih (jika tanpa pamrih tidak perlu takut).

7. Sepi ing pamrih rame ing gawe (sepi dalam pamrih, ramai dalam bekerja).

8. Mulat sarira hangrasa wani (berani mawas diri).
Setiap orang yang diberikan amanah untuk menjadi pimpinan seharusnya memberi manfaat bagi orang lain, sehingga dalam kepemimpinan tersebut tidak terkandung kesedihan orang lain.

Setiap orang yang diberikan amanah untuk memimpin harus berinstropeksi diri dan mencari yang benar dengan tidak melakukan perbuatan koruptif.

Setiap orang yang diberikan amanah untuk menjadi pemimpin seharusnya tidak berorientasi pada pamrih. Yang terpenting adalah kedamaian, ketentraman, aman, kebahagiaan, dan kemuliaan bagi semua orang yang ia pimpin.

Setiap orang yang diberikan amanah untuk menjadi pemimpin seharusnya bekerja keras dan tak perlu banyak pamrih (mengharapkan sesuatu). Meninggalkan kesan baik pada orang yang kita bantu bernilai jauh lebih luar biasa daripada sesuatu yang kita harapkan.

Setiap orang yang diberikan amanah untuk menjadi pemimpin seharusnya berani melihat dirinya sendiri dengan segala kekurangannya dan selalu siap mendapat kritik dari siapapun dan kapanpun. 
hukum pidana dengan sanksinya yang berupa pidana. ${ }^{17}$ Usaha pencegahan dan penanggulangan kejahatan dengan hukum pidana pada hakikatnya juga merupakan bagian dari usaha penegakan hukum, khususnya penegakan hukum pidana. ${ }^{18}$ Fungsionalisasi pencegahan dan penanggulangan kejahatan dengan sarana kebijakan hukum pidana dilalui dengan beberapa tahap, yakni tahap formulasi (kebijakan legislatif atau kebijakan kriminalisasi), tahap aplikasi (kebijakan yudikatif atau kebijakan yudisial, dan tahap eksekusi (kebijakan eksekutif atau kebijakan administratif). ${ }^{19}$

Sudarto pernah mengemukakan, apabila hukum pidana hendak digunakan, hendaknya dilihat dalam hubungan keseluruhan kebijakan hukum pidana atau "social defence planning" yang inipun harus merupakan bagian integral dari rencana pembangunan nasional. ${ }^{20}$ Dengan kata lain, usaha-usaha rasional untuk mengendalikan atau menanggulangi kejahatan (kebijakan hukum pidana) sudah barang tentu tidak hanya dengan menggunakan sarana penal, tetapi dapat juga dengan menggunakan sarana-sarana nonpenal. ${ }^{21}$

Pendekatan kebijakan hukum pidana melalui integrasi antara upayaupaya penal dengan nonpenal adalah suatu keniscayaan. Mengenai hal ini,
Barda Nawawi Arief memberikan ulasan yang sangat penting, yakni: ${ }^{22}$

Usaha-usaha nonpenal ini dapat meliputi bidang yang sangat luas sekali di seluruh sektor kebijakan sosial. Tujuan utama dari usaha-usaha nonpenal itu adalah memperbaiki kondisi-kondisi sosial tertentu. Namun, secara tidak langsung, mempunyai pengaruh preventif terhadap kejahatan. Dilihat dari sudut politik kriminil (kebijakan hukum pidana, -peneliti), keseluruhan kegiatan preventif yang nonpenal itu sebenarnya mempunyai kedudukan yang sangat strategis, memegang posisi kunci yang harus diintensifkan dan diefektifkan. Kegagalan dalam menggarap posisi strategis ini justru akan berakibat sangat fatal bagi usaha penanggulangan kejahatan.

The Asian Regional Ministerial on Transnational Crime di Manila tanggal 23-25 Maret 1998 menyepakati langkahlangkah kebijakan penanggulangan korupsi yang tertuang dalam "Manila Declaration on the Prevention and Control of Transnational Crime". Salah satu langkahnya adalah mengembangkan tindakan-tindakan pencegahan dan pengawasan untuk memajukan budaya pertanggungjawaban dan transparansi (aculture of accountability and transparency) dengan melibatkan peran serta masyarakat secara aktif. ${ }^{23}$

Dalam konteks ini, usaha menjadikan pitutur luhur untuk pemberantasan korupsi di Indonesia, khususnya pada

17 Muladi dan Barda Nawawi Arief, Teori-Teori dan Kebijakan Pidana (Alumni 2010) 148.

18 Barda Nawawi Arief, Bunga Rampai Kebijakan Hukum Pidana: Perkembangan Penyusunan Konsep KUHP Baru (Kencana 2011) 28.

19 Barda Nawawi Arief, Masalah Penegakan Hukum dan Kebijakan Hukum Pidana dalam Penanggulangan Kejahatan (Kencana 2014) 78-79.

Sudarto, Op.Cit., 104.

Muladi dan Barda Nawawi Arief, Op.Cit., 158.

Ibid., 159.

Barda Nawawi Arief, Op.Cit.,139. 
aspek pencegahan, dalam perspektif kebijakan hukum pidana dapat dimaknai sebagai pengejawantahan upaya strategis untuk memperbaiki kondisikondisi sosial yang menjadi penyebab lahirnya praktik korupsi. Dalam hal ini, secara tidak langsung, konkritisasi pitutur luhur mempunyai pengaruh preventif terhadap kejahatan korupsi. Selebihnya, tentu harus tetap diingat, pemberantasan korupsi adalah keterpaduan antara pencegahan dan penindakan.

Sebenarnya, pitutur luhur masih diharapkan, disukai, dan diberlakukan oleh masyarakat luas sampai sekarang. Buktinya, pitutur luhur sering disampaikan kepada peserta didik maupun masyarakat, baik secara lisan atau tertulis, seperti dalam kegiatan belajarmengajar di sekolah atau madrasah, pengajian di masjid atau musala, perkumpulan rukun tetangga atau rukun warga, sarasehan, rapat-rapat dinas, seminar, dan sebagainya. ${ }^{24}$ Oleh karena itu, usaha konkritisasi pitutur luhur untuk pemberantasan korupsi di Indonesia dapat dilakukan dengan berbagai cara strategis, misalnya melalui dunia pendidikan ${ }^{25}$, seni dan budaya, serta kegiatan-kegiatan yang melibatkan partisipasi masyarakat secara luas.

Mentransformasikan nilai, pemikiran, atau ajaran di masa lalu untuk ditarik ke masa kini memang sulit, tapi bukan berarti tidak bisa. Hal tersebut dikarenakan kearifan lokal menjadi diskursus. Ketika menjadi pemimpin, orang Jawa memiliki beberapa semboyan dan pandangan hidup yang selalu harus dilaksanakan agar kepemimpinannya dapat berjalan dengan baik karena diiringi dengan sikap-sikap yang arif dan bijaksana. ${ }^{26}$ Oleh karenanya, konkritisasi pitutur luhur merupakan upaya pemberantasan korupsi di Indonesia, khususnya dalam hal pencegahan.

Bambang Widjojanto, dalam sebuah acara Anti-Corruption Summit pada 2005 yang lalu, sebagaimana dikutip oleh Denny Indrayana, menguatkan: ${ }^{27}$

Substansi dan gaya optimistik seperti ini (misalnya, pitutur luhur, -penulis) perlu mulai ditradisikan untuk membangun "sugesti positif" masyarakat yang (rupanya diam-diam) sudah "tersugesti secara negatif" dengan berbagai cerita muram dan gagal penanganan kasus korupsi di beberapa tempat. ... . Membangun sugesti positif dalam

${ }_{24} \quad$ Sukirno, 'Pengkajian dan Pembelajaran Pitutur Luhur sebagai Pembentuk Karakter Peserta Didik' (2013) Jurnal Pendidikan Karakter 1, 109.

25 Pada faktanya saat ini, sebagian peserta didik hanya mementingkan kelulusan saja. Peserta didik dianggap cerdas manakala mereka mampu memperoleh nilai tinggi dalam ujian, meskipun dilakukan dengan cara-cara yang tidak jujur dan tidak beretika. Padahal, pengajaran pendidikan integritas di institusi pendidikan merupakan instrumen strategis dan efektif untuk mengampanyekan sekaligus menanamkan nilai-nilai antikorupsi kepada segenap anak bangsa. Tak berlebih kiranya menyebut pitutur luhur dapat dijadikan salah satu aspek dalam instrumen strategis pada pengajaran integritas di institusi pendidikan. Gustin Zulaihah, 'Pendidikan Integritas dan Dekulturasi Korupsi' dalam Edwin Syarif (ed), Integritas dalam Pandangan Mahasiswa: Solusi Problematika Sosial (Pusat Studi Indonesia-Arab (PSIA) Fakultas Adab dan Humaniora Universitas Islam Negeri (UIN) Syarif Hidayatullah 2011) 8-9.

26 Zuhdan A. Hudaya dan Sigit W.D. Nugroho, 'Kearifan Lokal Budaya Jawa sebagai Basis Model Kepemimpinan yang Efektif' (2013) < http://jp.feb.unsoed.ac.id/index.php/sca-1/article/ viewFile/222/227> diakses 23 Agustus 2017.

27 Denny Indrayana, Op.Cit., 120. 
memerangi korupsi ini dalam bahasa Bambang Widjojanto disebut dengan upaya "mengupayakan perubahan imagi menjadi bukti". Maksudnya, melakukan perlawanan kultural secara sistematis dengan menciptakan berbagai istilah dan peribahasa antikorupsi yang membawa efek dramatis di masyarakat.

Dengan demikian, upaya pemberantasan korupsi melalui upaya integral antara pencegahan dan penindakan adalah suatu keniscayaan. Saratri Wilonoyudho mengutip Blanshard dalam Morallity and Politics menulis, berkaitan dengan korupsi, ada pertanyaan etikal: jika Anda tidak mau memberantas korupsi, apakah sebenarnya Anda setuju terhadap korupsi? ${ }^{28}$

\section{PENUTUP}

Usaha menjadikan pitutur luhur untuk pemberantasan korupsi di Indonesia dalam perspektif kebijakan hukum pidana dapat dimaknai sebagai pengejawantahan upaya strategis untuk memperbaiki kondisi-kondisi sosial yang menjadi penyebab lahirnya praktik korupsi. Dalam hal ini, secara tidak langsung, konkritisasi pitutur luhur mempunyai pengaruh preventif terhadap kejahatan korupsi. Selebihnya, tentu harus tetap diingat, pemberantasan korupsi adalah keterpaduan antara pencegahan dan penindakan. Oleh karena itu, usaha konkritisasi pitutur luhur untuk pemberantasan korupsi di Indonesia dapat dilakukan dengan berbagai cara strategis, misalnya melalui dunia pendidikan, seni dan budaya, serta kegiatan-kegiatan yang melibatkan partisipasi masyarakat secara luas.

\section{DAFTAR BACAAN}

\section{Buku}

Arief, Barda Nawawi, Bunga Rampai Kebijakan Hukum Pidana: Perkembangan Penyusunan Konsep KUHP Baru (Kencana 2011).

, Masalah Penegakan Hukum dan Kebijakan Hukum Pidana dalam Penanggulangan Kejahatan (Kencana 2014).

Indrayana, Denny, Negeri Para Mafioso: Hukum di Sarang Koruptor (Penerbit Buku Kompas 2008).

Muladi dan Arief, Barda Nawawi, Teori-Teori dan Kebijakan Pidana (Alumni 2010).

Prawiroatmodjo, S., Bausastra JawaIndonesia (Express dan Marfiah 1957).

Rianto, Bibit S. dan Meuko, Nurlis, Koruptor, Go to Hell! (Mengupas Anatomi Korupsi di Indonesia) (Penerbit Hikmah 2010).

Sudarto, Hukum dan Hukum Pidana (Alumni 2000).

Sudjana, Eggi, Republik Tanpa KPK, Koruptor Harus Mati (JP Books 2008).

Sunardi, "Pitutur Luhur Budaya Jawa sebagai Pedoman Hidup di Era Globalisasi", dalam Edi Subroto, dkk, Prosiding Seminar Nasional: Reaktualisasi Nilai-Nilai Luhur Budaya Jawa melalui Bahasa Jawa (Program Studi Pendidikan Bahasan

$\overline{28}$ Saratri Wilonoyudho, 'Korupsi Merobohkan Nasionalisme’ (2014) Jawa Pos, 21 Mei 2011, 4. 
dan Sastra Daerah Universitas Veteran Bantara Sukoharjo 2012).

Syarif, Edwin (ed), Integritas dalam Pandangan Mahasiswa: Solusi Problematika Sosial (Pusat Studi Indonesia-Arab (PSIA) Fakultas Adab dan Humaniora Universitas Islam Negeri (UIN) Syarif Hidayatullah Jakarta 2011).

\section{Jurnal}

Badjuri, Achmad, "Peranan Komisi Pemberantasan Korupsi (KPK) sebagai Lembaga Antikorupsi di Indonesia" (2011) 18 Jurnal Bisnis dan Ekonomi 1.

Endarto, "Kendala KPK dalam Pemberantasan Korupsi di Indonesia" (2014) 1 Jurnal Lingkar Widyaiswara 1.

Pratama, Alfian Wahyu, "Kebijakan Hukum Pidana dalam Menanggulangi Tindak Pidana Korupsi yang Dilakukan Korporasi (Studi Pembaruan Pidana dalam Menanggulangi Tindak Pidana Korupsi yang Dilakukan Korporasi)" (2013) <http:// jurnal.untan.ac.id/index.php/ nestor/article/view/977> diakses 1 Januari 2018.

Runtukahu, Ernest, "Korupsi dalam Konsep Hukum Formal dan Konsep Hukum Material” (2012) 1 Jurnal Lex Crimen 1.

Sugiarto, Totok, "Peranan Komisi Pemberantasan Korupsi (KPK) dalam Pemberantasan Tindak Pidana Korupsi di Indonesia" (2013) 18 Jurnal Cakrawala Hukum 1.
Sukirno, "Pengkajian dan Pembelajaran Pitutur Luhur sebagai Pembentuk Karakter Peserta Didik” (2013) Jurnal Pendidikan Karakter 1.

\section{Surat Kabar}

Kompas, "Upaya-Upaya Pelemahan KPK" (2015) Kompas, 24 Januari 2015.

Wilonoyudho, Saratri, "Korupsi Merobohkan Nasionalisme" (2014) Jawa Pos, 21 Mei 2011.

\section{Internet}

Hudaya, Zuhdan A. dan Nugroho, Sigit W.D., "Kearifan Lokal Budaya Jawa sebagai Basis Model Kepemimpinan yang Efektif" (2013) <http:// jp.feb.unsoed.ac.id/index.php/sca1 / article / viewFile / 222 / 227 > diakses 23 Agustus 2017.

Kompas, "Drama Rapat Paripurna DPR Loloskan Hak Angket KPK...” (2017) <http:/ / nasional.kompas.com / $\mathrm{read} / 2017 / 04 / 29 / 10095821 / \mathrm{dr}$ a m a.r a pat.pari purna. d p r. loloskan. hak. angket. kpk.? page $=1>$ diakses 25 Juli 2017.

Kompas, "Ini 45 Anggota DPR Pengusul Revisi UU KPK”, (2016) <http:// nasional.kompas.com/read/2016/ 02/05/10524641/Ini.45. Anggota. DPR.Pengusul.Revisi.UU.KPK> diakses 25 Juli 2017.

Kompas, "Penyidik KPK Novel Baswedan Disiram Air Keras", (2017) <http:// nasional.kompas.com/read/2017/ 
04 / 11 / 07372071 / penyidik. kpk.novel.baswedan.disiram.air.keras> diakses 25 Juli 2017.

Laksono, Dave Akbarshah Fikarno, "Efektivitas Politik Pemberantasan Korupsi" (2017) <http://koransindo.com/page/news/2017-0724/1/1/Efektivitas_Politik_ Pemberantasan_Korupsi>diakses 23 Agustus 2017. 
